\title{
Validation of Pin Power Calculations Using DYN3D on MIDICORE Benchmark
}

\author{
- Kuchyn 0. \\ State Enterprise "State Scientific and Technical Center for Nuclear and Radiation Safety" \\ ORCID: $h$ ttps://orcid.org/0000-0001-9334-4977 \\ - Ovdiienko I. \\ State Enterprise "State Scientific and Technical Center for Nuclear and Radiation Safety" \\ ORCID: https://orcid.org/0000-0002-7016-1841 \\ - Khalimonchuk V. \\ State Enterprise "State Scientific and Technical Center for Nuclear and Radiation Safety" \\ ORCID: https://orcid.org/0000-0002-9285-661X \\ - leremenko $M$. \\ State Enterprise "State Scientific and Technical Center for Nuclear and Radiation Safety" \\ ORCID: https://orcid.org/0000-0002-5411-7920
}

\begin{abstract}
Three-dimensional code DYN3D is widely used for the calculation of steady states and transients in light water reactors with hexagonal fuel assemblies like VVER. The capability of pin-by-pin power calculation is implemented in the code through an intranodal power reconstruction approach. The calculations of pin power distribution using DYN3D were performed for AER MIDICORE benchmark for the validation of given extension and developed cross-section library. MIDICORE VVER-1000 core periphery power distribution benchmark was proposed on the 20th Symposium of AER. It is a 2D calculation benchmark based on the VVER-1000 core cold state geometry taking into account the geometry of explicit radial reflector. The main issue of MIDICORE benchmark is to provide the reference solution for the validation of pin-by-pin power distribution at the VVER-1000 core periphery calculated by few-group diffusion codes.

Various 3D neutron kinetics nodal solvers HEXNEM1, HEXNEM2 and HEXNEM3 are used in DYN3D for neutron flux distribution calculation. The AER MIDICORE benchmark was solved using all solvers implemented in DYN3D with regard to the three most representative fuel assemblies. Considered fuel assemblies are placed both in the inner part and in the peripheral part of the core, and contain the pin with integrated gadolinium burnable absorber. This paper provides results of comparing the effective multiplication factor, assembly-wise power distribution and pin-by-pin power distribution calculated by DYN3D with benchmark data.
\end{abstract}

Ke y w o r d s: DYN3D code, VVER, benchmark, few-group cross-sections, pin power

(c) Kuchyn O., Ovdiienko I., Khalimonchuk V., leremenko M., 2019

$\mathrm{T}$ The MIDICORE calculation benchmark was presented on the 20th Symposium of AER by Mr. P. Mikolas [1]. It is based on the calculation of restricted part of the VVER-1000 core in cold state. Proposed benchmark consists of fresh fuel assemblies surrounded by real VVER-1000 radial reflector. The core segment with the fuel assembly (FA) types and radial reflector is presented in Fig. 1. The reflection boundary conditions are used on the azimuthal surfaces numbered as 1 and 2 in Fig. 1, and the total absorption boundary condition (leakage to the vacuum) is used on the cylindrical outer boundary numbered as 3. The reflection boundary conditions are used in axial directions. MCNP-4C Monte Carlo computer code and ENDF/B6 cross-section library were used to obtain benchmark solution.

The main issue of MIDICORE benchmark is to provide the reference solution for validation of pin-by-pin power distribution at the VVER1000 reactor core periphery calculated by few-group diffusion codes. The MIDICORE benchmark objectives are:

- Keff calculation;

- Assembly-wise power distribution;

- Pin-by-pin power distribution in FA No. 6 (A200), FA No. 7 (P36E9), FA No. 9 (P40E9). FA numbering is presented in Fig.1.

Detailed description of a 2D mathematical benchmark of MIDICORE is presented in [1]. Fuel types P36E9 and P40E9 contain 9 Gd-fuel pins. 


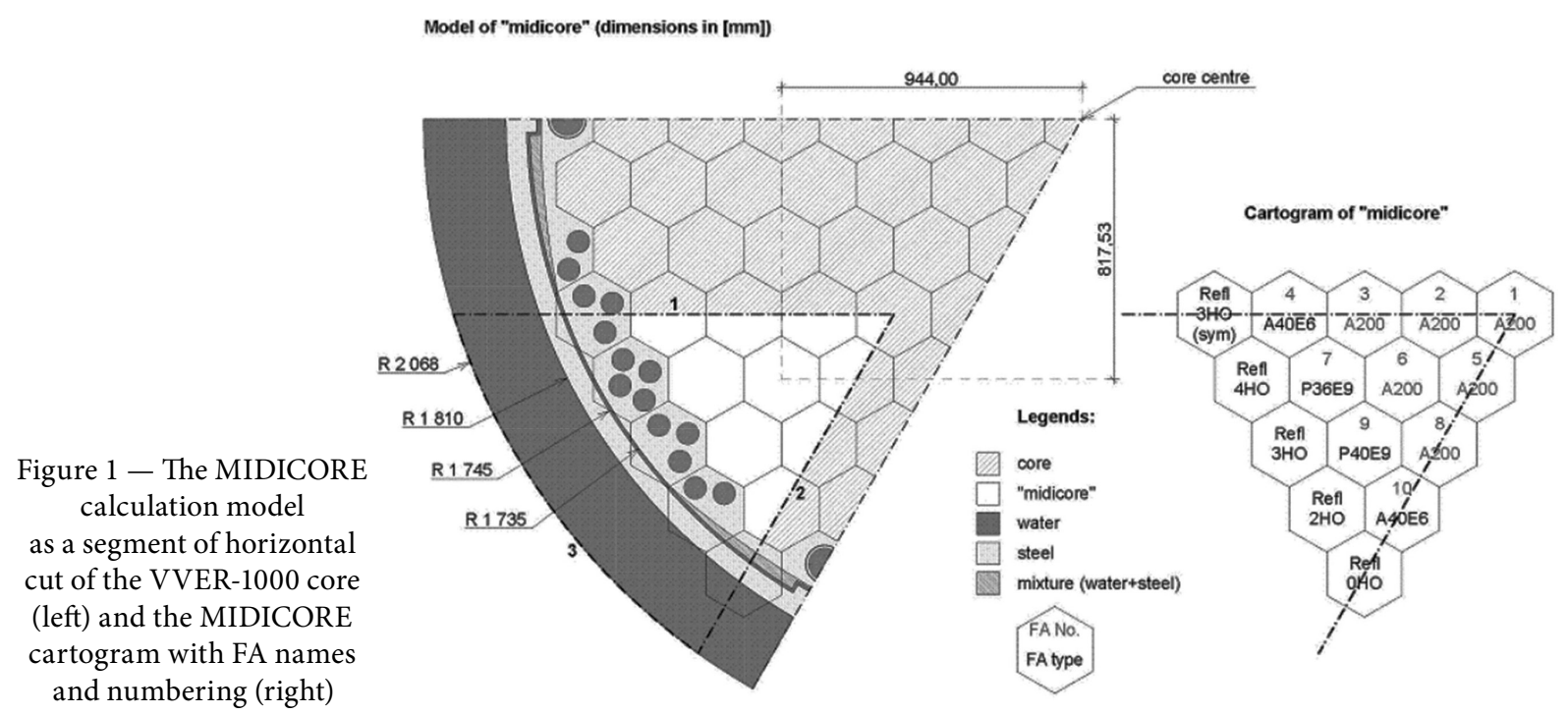

\section{Results of calculations}

In accordance with MIDICORE benchmark description, input file for DYN3D calculation was developed. DYN3D is three-dimensional computer code for reactor core calculation in hexagonal geometry [2]. It solves two-group diffusion equations by nodal method. To find neutron flux distribution inside the nodes, two different approximations are used in DYN3D [3]. The first one is HEXNEM1 method in which the nodes are coupled only by the averaged fluxes and currents at the hexagon sides. In the second approximation, side-averaged and cornerpoint values of fluxes and currents are used for the coupling of nodes for flux definition (HEXNEM2). In that way, HEXNEM2 method additionally includes the corner points in comparison with HEXNEM1 method and uses functions that are more exponential in the flux expansion. The main difference of the HEXNEM3 method is the additional use of tangentially weighted exponential functions and the coupling of neighboring nodes by tangentially weighted fluxes and currents on node surfaces [4]. Hence, one should expect that HEXNEM3 is more accurate method than HEXNEM1 and HEXNEM2.

Two-group diffusion cross-section sets for MIDICORE fuel assemblies are generated by HELIOS code. They are approximated by polynomial dependencies, which are conventionally used in DYN3D calculation of VVER reactor cores. Assembly discontinuity factors (ADF) for fuel assemblies and reference discontinuity factors (RDF) for reflector are used in DYN3D calculations [5]. To model MIDICORE reflector, two-group diffusion crosssection sets and RDF values were used for real geometry of VVER-1000 reflector. These sets were obtained by P. Petkov using HELIOS and MARIKO codes.

DYN3D does not allow modeling reflection boundary conditions in $60^{\circ}$ symmetry of reactor core (only rotational symmetry is possible). Full-scale reactor core in $360^{\circ}$ symmetry for MIDICORE benchmark is used in DYN3D as presented in Fig.2 to model reflection boundary conditions on surfaces 1 and 2 (Fig.1). At the outer boundary of reflector, the vacuum boundary conditions are put. The reflection boundary conditions are used in axial direction.

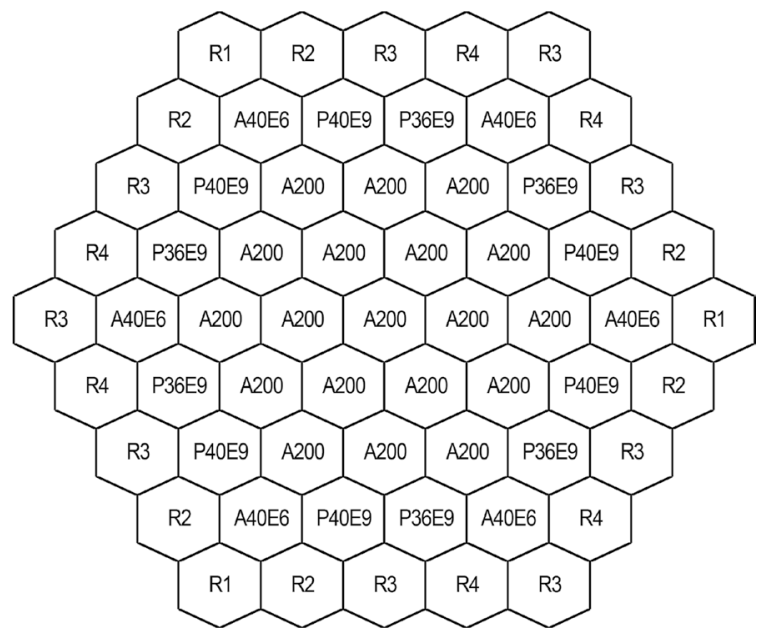

Figure 2 - The MIDICORE calculation model in DYN3D 


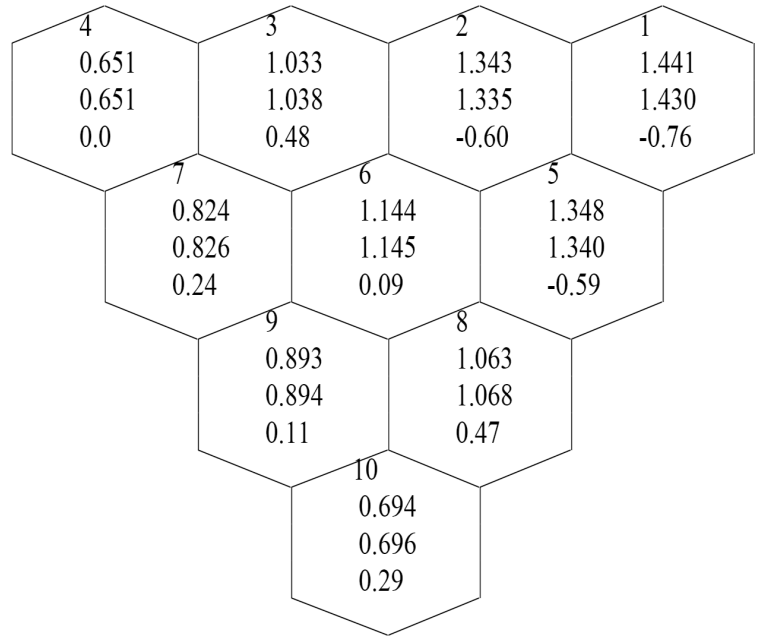

Figure -3 Relative assembly-wise power distribution for the MIDICORE model.

First number - benchmark solution,

second number - DYN3D/HEXNEM1 calculation, third number - difference [(DYN3D/benchmark-1)*100\%] Mean square deviations of fuel assemblies power $-0.56 \%$

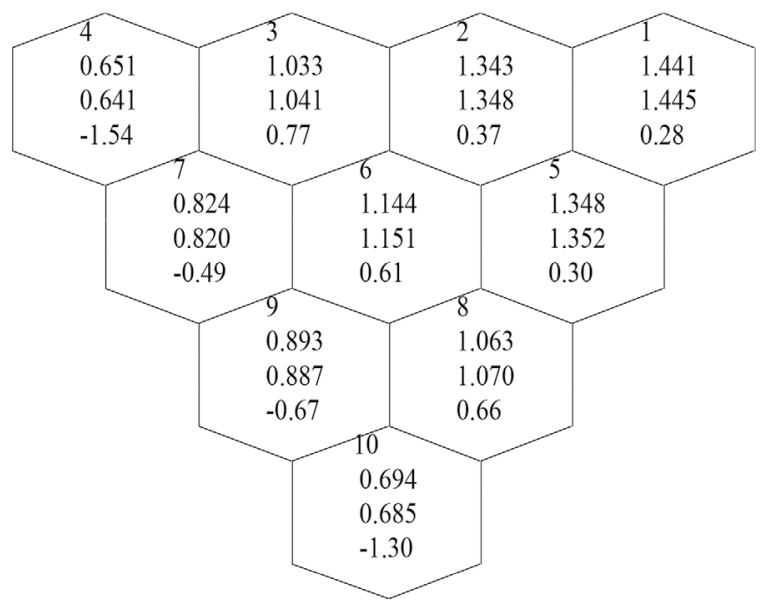

Figure 5 - Relative assembly-wise power distribution for the MIDICORE model. First number - benchmark solution,

second number - DYN3D/HEXNEM3 calculation, third number - difference [(DYN3D/benchmark-1)*100\%] Mean square deviations of fuel assemblies power $-0.67 \%$

Table 1 presents results of effective multiplication factor calculation obtained by DYN3D and compared with benchmark solution. HEXNEM1 and HEXNEM2 methods underestimate Keff, and values of underestimation are $520 \mathrm{pcm}$ for HEXNEM1 and 640 pcm for HEXNEM2.

Fig.3, Fig.4 and Fig.5 provide relative assembly-wise power distribution and their deviations from reference solution for the MIDICORE benchmark calculated by DYN3D using HEXNEM1, HEXNEM2 and

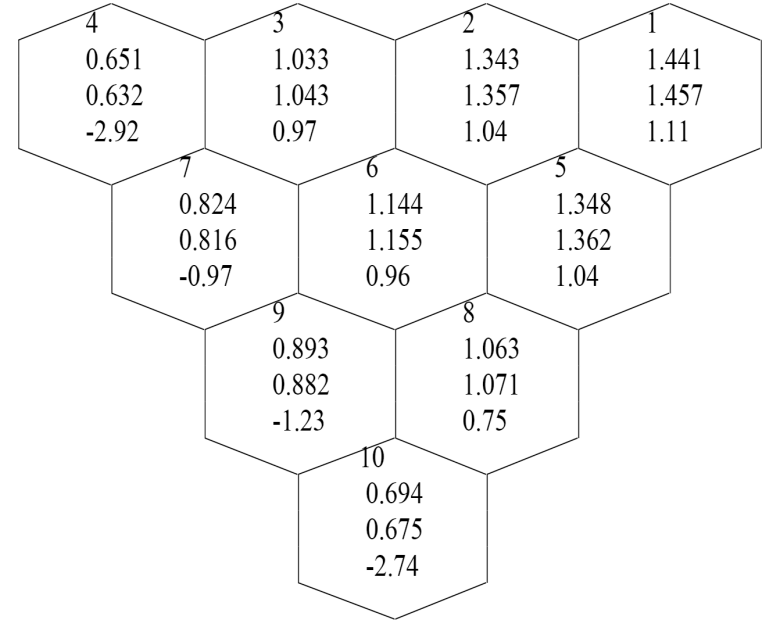

Figure - 4 Relative assembly-wise power distribution for the MIDICORE model.

First number - benchmark solution, second number - DYN3D/HEXNEM2 calculation, third number - difference [(DYN3D/benchmark-1)*100\%] Mean square deviations of fuel assemblies power $-1.36 \%$

Table 1 - Effective multiplication factor

\begin{tabular}{|l|c|c|}
\hline & $\mathbf{K}_{\text {eff }}$ & $\Delta \mathbf{K}_{\text {eff }}$ \\
\hline Benchmark & 1.04520 & - \\
\hline HEXNEM1 & 1.03999 & -0.0052 \\
\hline HEXNEM2 & 1.03877 & -0.0064 \\
\hline HEXNEM3 & 1.03939 & -0.0058 \\
\hline
\end{tabular}

HEXNEM3 methods. These figures show that HEXNEM1 method yields more accurate results for fuel assembly power than HEXNEM2 and HEXNEM3. Mean square deviations of fuel assembly power distribution for HEXNEM1, HEXNEM2 and HEXNEM3 methods are $0.5 \%$, $1.6 \%$ and $0.7 \%$, respectively.

Table 2 - Mean square deviations in pin power distribution

\begin{tabular}{|c|c|c|c|}
\hline \multirow{2}{*}{} & \multicolumn{3}{|c|}{ Fuel assembly type } \\
\cline { 2 - 4 } & A200 & P36E9 & P40E9 \\
\hline HEXNEM1 & 0.007 & 0.017 & 0.015 \\
\hline HEXNEM2 & 0.004 & 0.019 & 0.017 \\
\hline HEXNEM3 & 0.007 & 0.016 & 0.015 \\
\hline
\end{tabular}


Table 3-Maximal pin power difference

\begin{tabular}{|l|l|c|c|c|}
\hline \multirow{2}{*}{\multicolumn{2}{|c|}{}} & \multicolumn{3}{|c|}{ Fuel assembly type } \\
\cline { 3 - 5 } & pin number & A200 & P36E9 & P40E9 \\
\cline { 2 - 5 } & power difference & 46 & 1 & 1 \\
\hline \multirow{3}{*}{ HEXNEM1 } & pin number & 0.031 & 0.068 & 0.052 \\
\cline { 2 - 5 } & power difference & 224 & 56 & 56 \\
\hline \multirow{3}{*}{ HEXNEM3 } & pin number & 0.018 & 0.064 & 0.056 \\
\cline { 2 - 5 } & power difference & 56 & 276 & 276 \\
\hline
\end{tabular}

Table 4-Maximal pin power

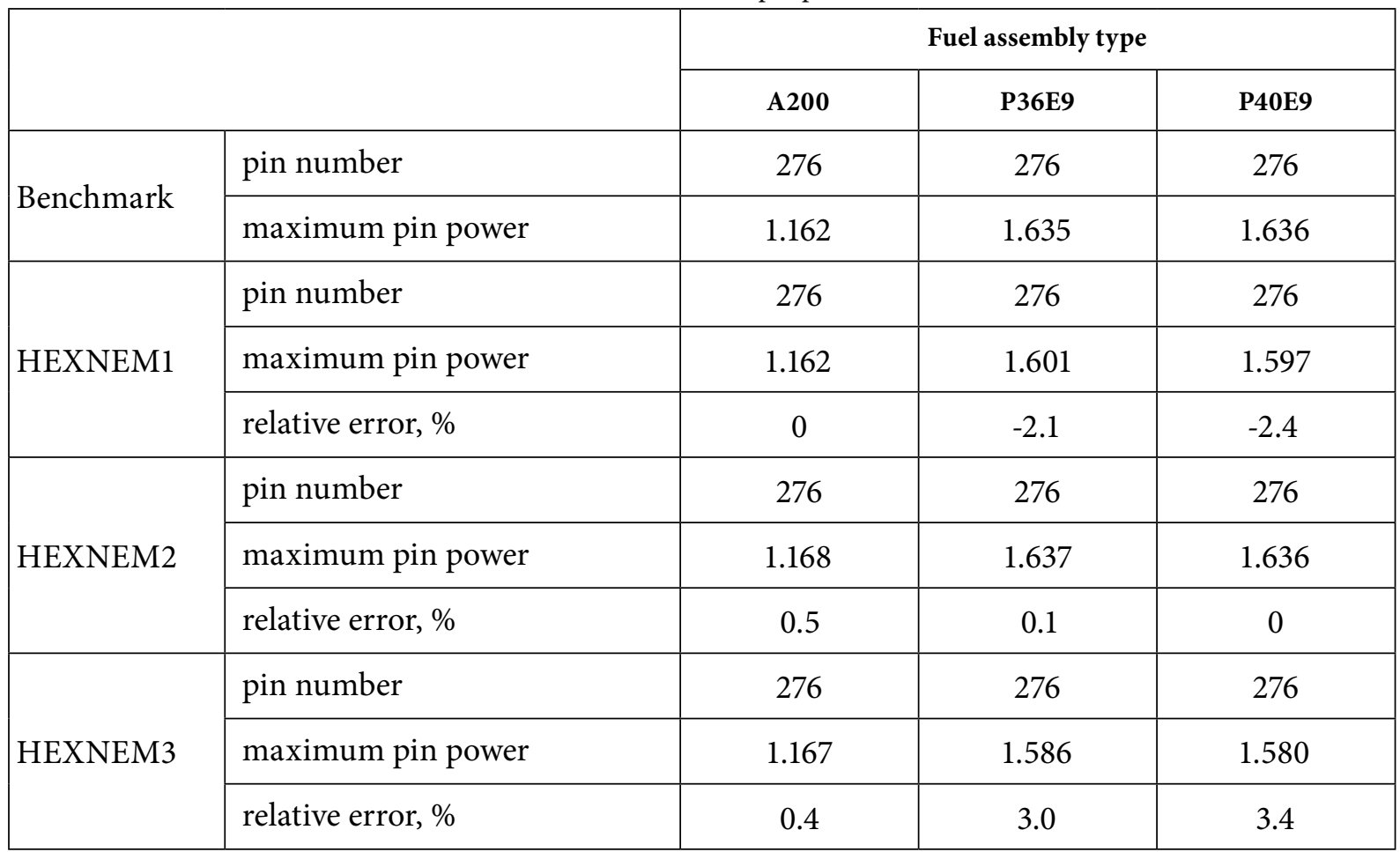

Fig.6-Fig. 14 and Tables 2-4 provide results of calculation of relative pin power distribution for FA's (A200, P36E9 and P40E9) calculated by DYN3D using HEXNEM1, HEXNEM2 and HEXNEM3 methods and their comparison with reference solution. Mean square deviations in pin power distribution between DYN3D calculation and benchmark solution (Table 2) present that HEXNEM2 method yields more accurate pin power for non-periphery fuel assembly (A200). For periphery fuel assemblies (P36E9 and P40E9) HEXNEM1 and HEXNEM3 yield more accurate result. Table 4 presents that HEXNEM2 predicts maximum value of pin power more accurate than HEXNEM1 and HEXNEM3 method.

Fig.10 and Fig.11 present that maximal deviation in pin power distribution with use of HEXNEM2 method $(\approx 6 \%)$ is observed in the area of fuel assembly close to the radial reflector (assemblies P36E9 and P40E9). For power reconstruction with use of HEXNEM3 method, the pin power at peripheral rows is more accurate and amounts up to $1.6 \%$ (Fig.13 and Fig.14). 


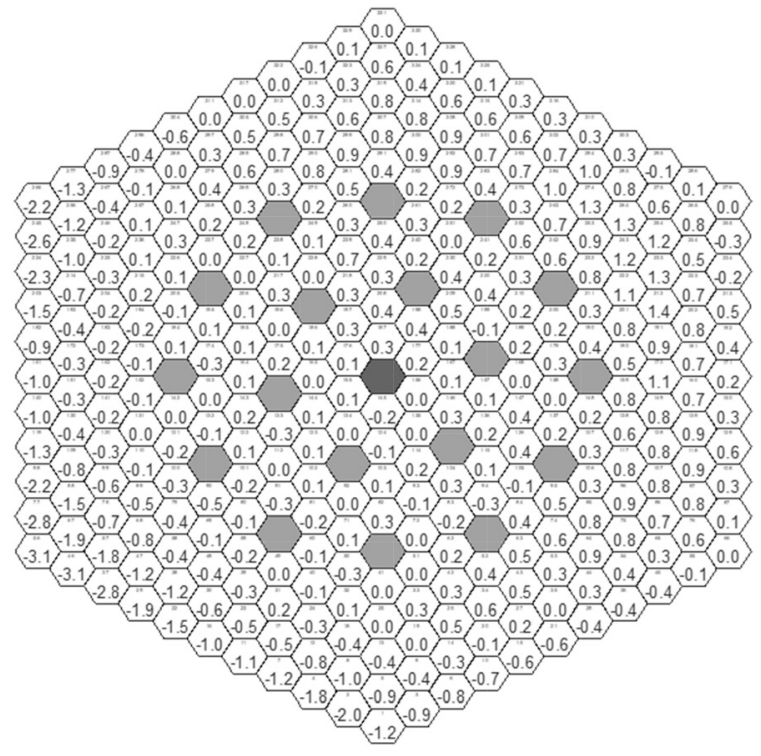

Figure 6-Distribution of differences in relative pin power for FA (A200) [(DYN3D/ HEXNEM1-benchmark)* $\left.{ }^{*} 100\right]$

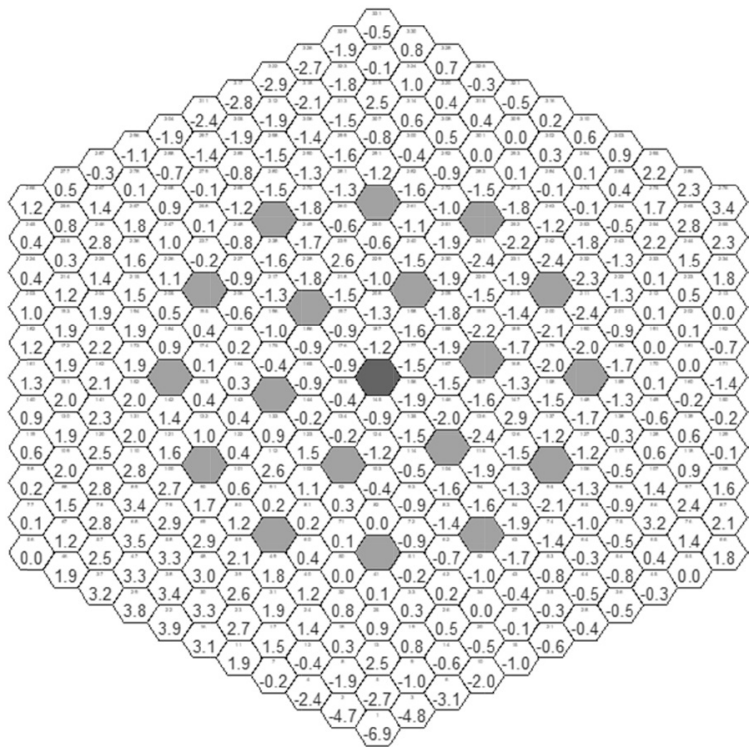

Figure 7 - Distribution of differences in relative pin power for $\mathrm{FA}(\mathrm{P} 36 \mathrm{E} 9)$ [(DYN3D/HEXNEM1 -benchmark $\left.)^{\star} 100\right]$

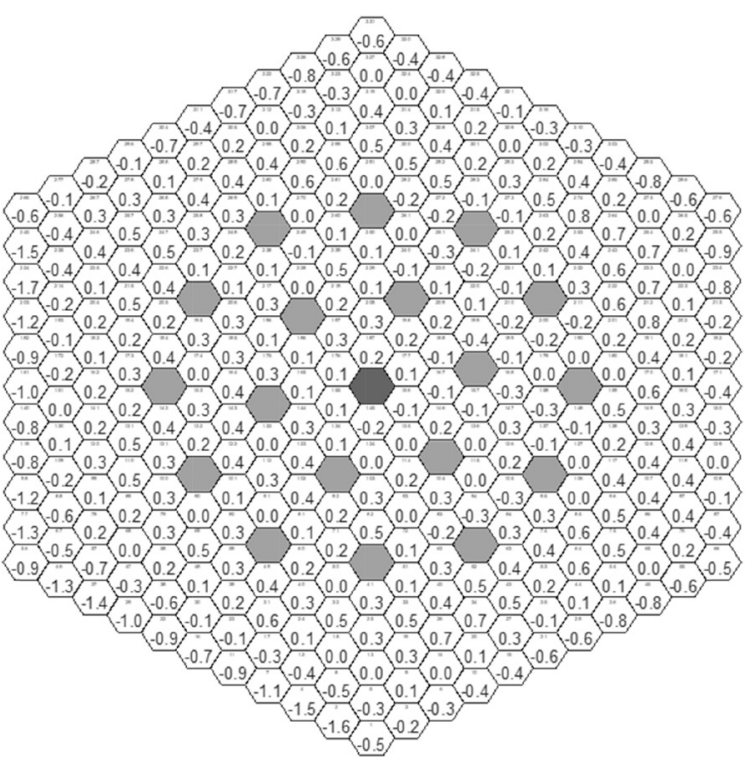

Figure 9-Distribution of differences in relative pin power for FA (A200) [(DYN3D/ HEXNEM2 -benchmark $)^{\star} 100$ ] 


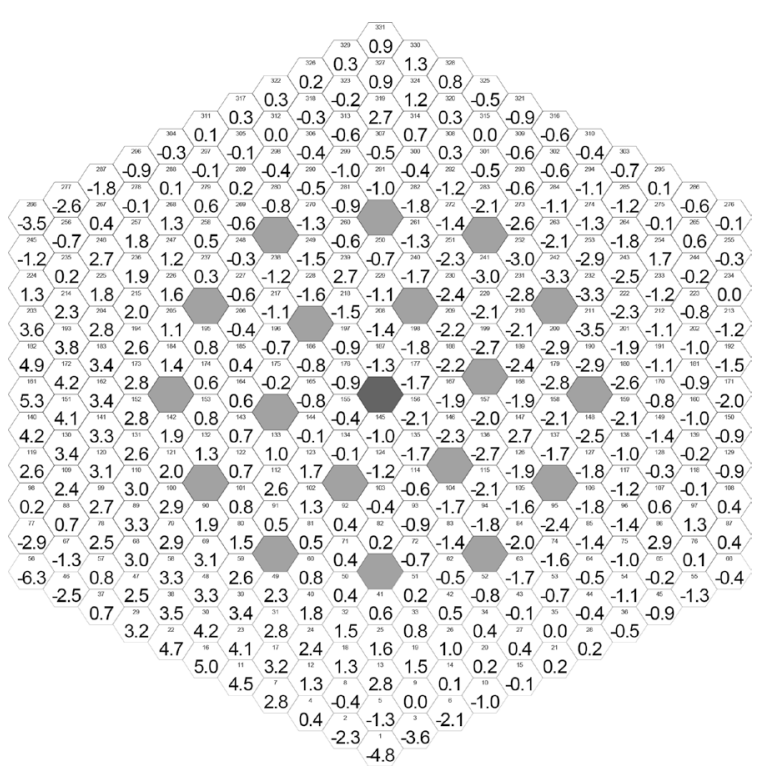

Figure $10-$ Distribution of differences in relative pin power for FA (P36E9) [(DYN3D/ HEXNEM2 -benchmark ${ }^{\star} 100$ ]

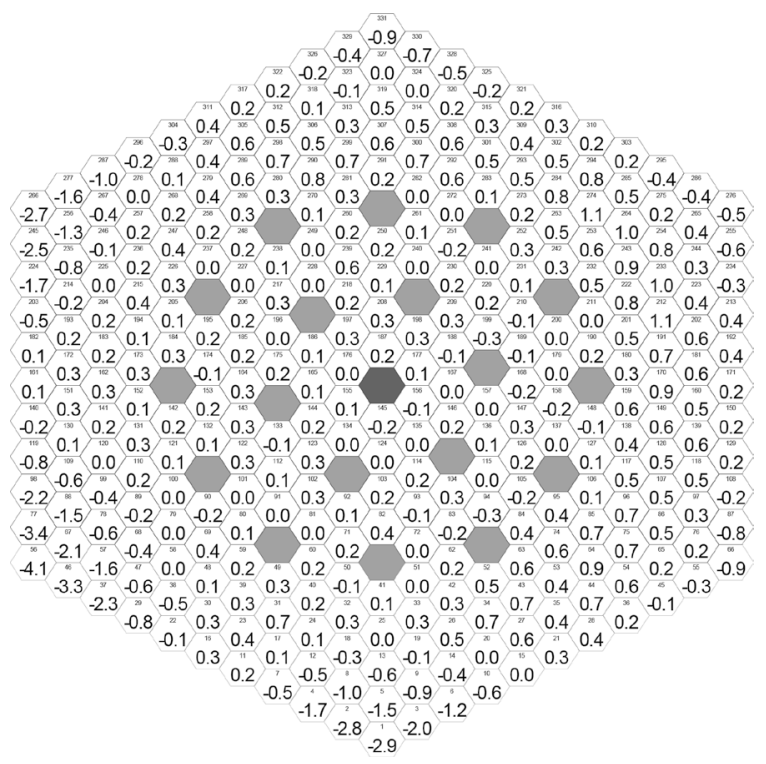

Figure 12 - Distribution of differences in relative pin power for FA (A200) [(DYN3D/ HEXNEM3 -benchmark)*100]

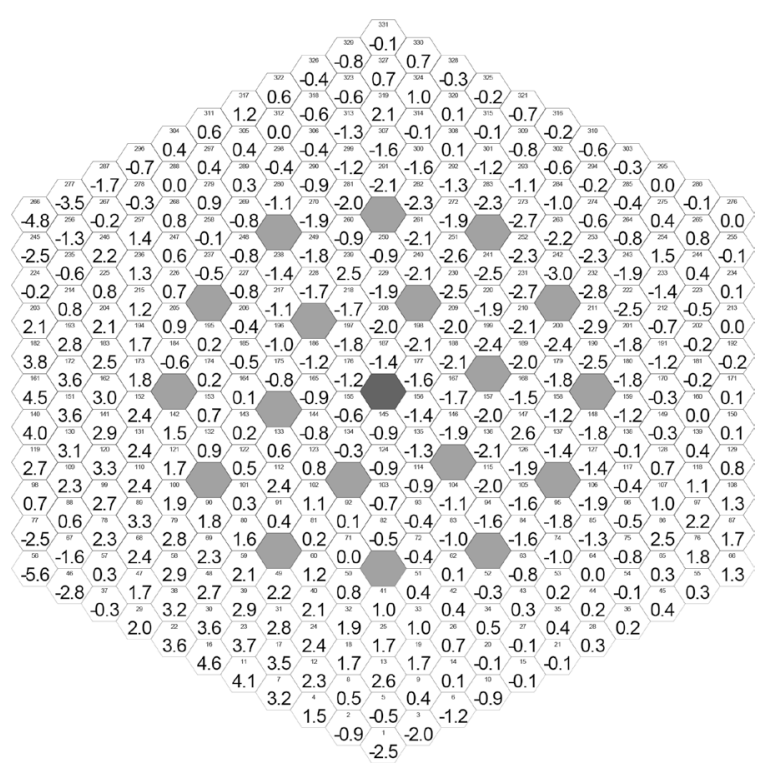

Figure 11 - Distribution of differences in relative pin power for FA (P40E9) [(DYN3D/ HEXNEM2 -benchmark)*100]

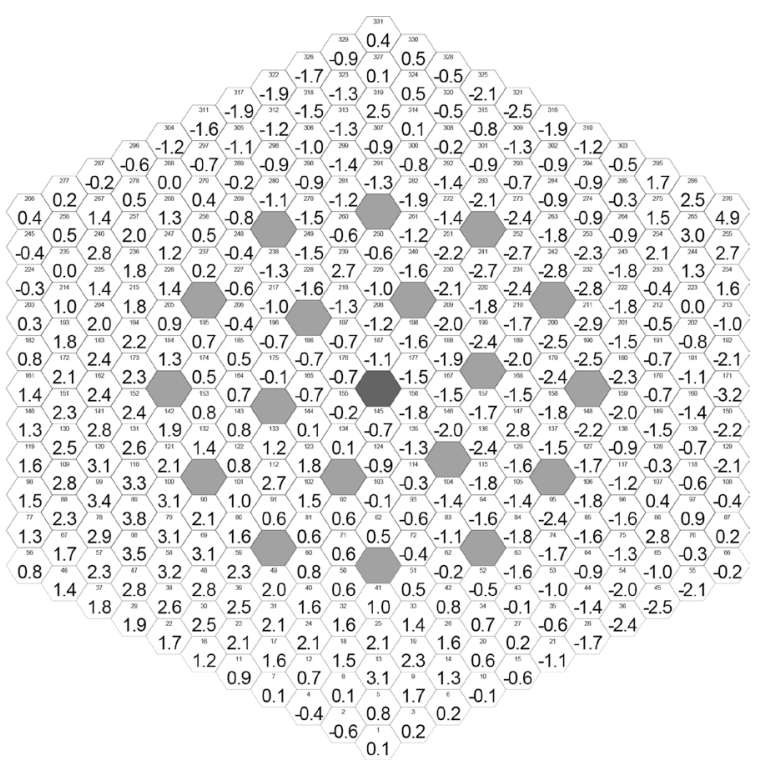

Figure $13-$ Distribution of differences in relative pin power for FA (P36E9) [(DYN3D/ HEXNEM3 -benchmark)*100] 


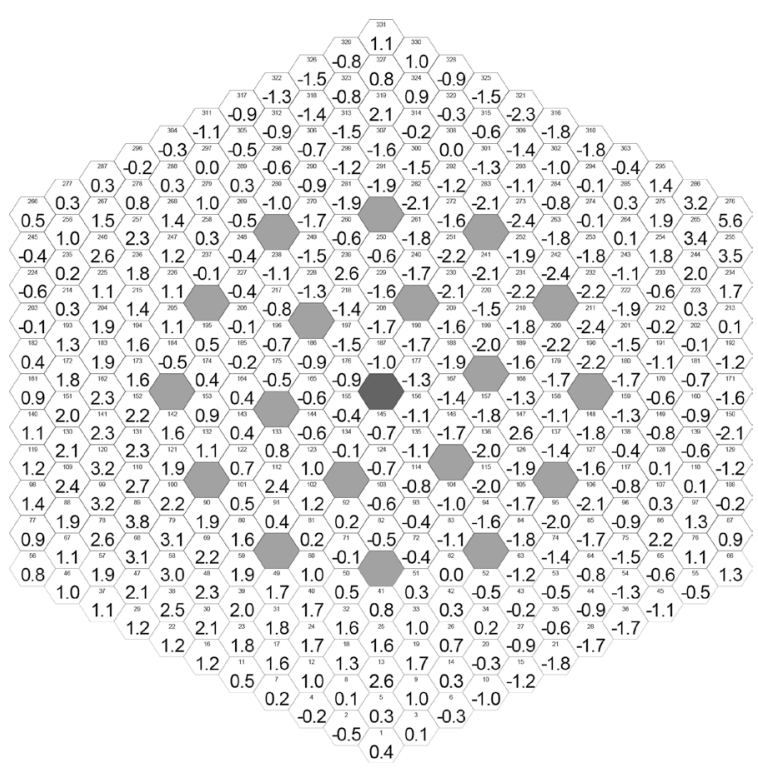

Figure $14-$ Distribution of differences in relative pin power for FA (P40E9) [(DYN3D/ HEXNEM3 -benchmark)*100]

\section{Conclusions}

1. HEXNEM1/HEXNEM2/HEXNEM3 methods implemented in DYN3D code predict the calculation of effective multiplication factor for MIDICORE benchmark with the accuracy $520 / 640 / 580 \mathrm{pcm}$, respectively.

2. HEXNEM1/HEXNEM2/HEXNEM3 methods yield mean square deviation from benchmark solution for assembly-wise power distribution $0.56 \% / 1.36 \% / 0.67 \%$, respectively.

3. HEXNEM2 method yields more accurate calculation of pin-by-pin power distribution for non-periphery fuel assembly (A200) in comparison with HEXNEM1 method.

4. For periphery fuel assemblies (P36E9 and P40E9), more great deviations of pin-by-pin power calculation are observed compared with non-periphery fuel assembly. Maximal deviation in pin power distribution is observed in the area of fuel assembly close to the radial reflector.

\section{References}

1. Krýsl, V., Mikoláš, P., Sprinzl, D., Švarný, J. (2010). MIDICORE VVER-1000 Core Periphery Power Distribution Benchmark Proposal, 20th SYMPOSIUM of AER on VVER Reactor Physics and Reactor Safety, Espoo, Finland.
2. Grundmann, U., Rohde, U., Mittag, S., Kliem, S. DYN3D Version 3.2. Code for calculation of transients in light water reactors with hexagonal or quadratic fuel elements. Description of models and methods.

3. Grundmann, U., Hollstein Rohde, F., Mittag, S., Kliem, S. (1999). A two-dimensional intranodal flux expansion method for hexagonal geometry, Nuclear Science and Engineering, No. 133, 201.

4. Bilodid, Y., Grundmann, U., Kliem, S. (2018). The HEXNEM3 nodal flux expansion method for the hexagonal geometry in the code DYN3D, Annals of Nuclear Energy, No. 116, pp.187-194.

5. Mittag, S., Petkov, P., Grundmann, U. (2003). Discontinuity factors for non-multiplying material in two-dimensional hexagonal reactor geometry, Annals of Nuclear Energy, No. 30, pp. 1347-1364.

\section{Валідація потвельних розрахунків програ- мою DYN3D на даних бенчмарку MIDICORE}

Кучин О.В., Овдієнко Ю.М., Халімончук В.А., єременко М.Л. Державне підприємство «Державний науково-технічний центр з ядерної та радіачійної безпеки», м. Київ, Україна

Тривимірний код DYN3D широко використовується для розрахунку стаціонарних станів і перехідних прочесів в легководних реакторах з тепловиділяючими збірками з гексагональних розташуванням ТВЕЛ, такими як ВВЕР. Можливість розрахунку потвельного енерговиділення реалізована в коді з використанням методу внутрішньої реконструкції потужності. Для валідації модуля розрахунку потвельного енерговиділення програмою DYN3D була розроблена бібліотека констант та виконані розрахунки AER MIDICORE бенчмарка. MIDICORE WWER-1000 бенчмарк був запропонований на 20-му СИмпозіумі AER. Це двовимірний бенчмарк, розроблений для активної зони реактора ВВЭР-1000 в холодному стані з урахуванням явного завдання радіального відбивача нейтронів. Основне завдання бенчмарка MIDICORE полягає в наданні еталонного рішення для перевірки потвельного розподілу потужності на периферії активної зони реактора ВВEP-1000, розрахованого декількома малогруповими дифузійними кодами.

Різні нодальні підходи до рішення тривимірного рівняння дифузії нейтронів HEXNEM1, HEXNEM2 і HEXNEM3 використовуються в DYN3D для розрахунку розподілу нейтронного потоку. Рішення бенчмарка AER MIDICORE було виконано з використанням всіх реалізованих в коді DYN3D підходів щодо трьох найбільш представницьких паливних збірок. Розглянуті тепловиділяючі збірки розміщені як у внутрішній частині, так і в периферійній частині активної зони реактора і містять твели з інтегрованим гадолініевим вигоряючим поглиначем. В даній роботі наведені результати порівняння ефективного коефіцієнта розмноження нейтронів, а також розподілу енерговиділення як в активній зоні, так і в окремuх TB3, розрахованих програмою DYN3D, з результатами бенчмарка.

Ключ ов і слов в: програма DYN3D, BBEP, бенчмарк, малогрупові константи, потвельні енерговиділення. 


\section{Валидация потвельних расчетов програм- мой DYN3D на данных бенчмарка MIDICORE}

Кучин А.В., Овдиенко Ю.Н., Халимончук В.А., Еременко М.Л.

Государственное предприятие «Государственный научно-технический центр по ядерной и радиачионной безопасности», г. Киев, Украина

Трехмерный код DYN3D широко используется для расчета стачионарных состояний и переходных процессов в легководных реакторах степловыделяющими сборками с гексагональным расположением твэл, такими как ВВэР. Возможность расчета потвэльного энерговыделения реализована в коде сиспользованием метода внутренней реконструкции мощности. Для валидации модуля расчета потвельного энерговыделения программой DYN3D была разработана библиотека констант и выполнены расчеты AER MIDICORE бенчмарка. MIDICORE WWER1000 бенчмарк был предложен на 20-м Симпозиуме AER. Это двумерный бенчмарк, разработанный для активной зоны реактора ВВЭР-1000 в холодном состоянии сучетом явного задания радиального отражателя нейтронов. Основная задача бенчмарка MIDICORE заключается в предоставлении эталонного решения для проверки потвэльного распределения мощности на периферии активной зоны реактора ВВЭР-1000, рассчитанного несколькими малогрупповыми диффузионными кодам.
Различные нодальные подходы к решению трехмерного уравнения диффузии нейтронов HEXNEM1, HEXNEM2 и HEXNEM3 используются в DYN3D для расчета распределения нейтронного потока. Решение бенчмарка AER MIDICORE было выполнено с использованием всех реализованных в коде DYNN3D подходов в отношении трех наиболее представительных топливных сборок. Рассматриваемые тепловыделяющие сборки размещены как во внутренней части, так и в периферийной части активной зоны реактора и содержат твэлы с интегрированным гадолиниевым выгорающим поглотителем. В данной работе приведены результаты сравнения эффективного коэффициента размножения нейтронов, а также распределения энерговыделения как в активной зоне, так и в отдельных ТВС, рассчитанных программой DYN3D с результатами бенчмарка.

Ключевые слова: программа DYN3D, BBЭP, бенчмарк, малогруповые константы, потвельные энерговыделения. 